\title{
LEX PORTUS
}

2018, Vol.2, Art.9

\section{Степанов С. В. Господарські суди України в системі органів судової влади}

\section{Sergiy Stepanov*. Economic courts of Ukraine are in the system of judicial authorities}

Suggested citation:

Степанов, С.В. (2018). Господарські суди України в системі органів судової влади. Lex Portus, 2, 110-117. https://doi.org/10.26886/2524-101X.2.2018.9

Stepanov, S.V. (2018). Hospodarski sudy Ukrainy v systemi orhaniv sudovoi vlady [Economic courts of Ukraine are in the system of judicial authorities]. Lex Portus, no. 2, 110-117. https://doi.org/10.26886/2524-101X.2.2018.9 [in Ukrainian].

*Sergiy Stepanov. PhD in Law, Associate Professor of the Department of Civil and Labour Law of National University "Odessa Maritime Academy" (8, Didrihsona St., Odessa, Ukraine).

\section{ABSTRACT}

During the proclamation of independence, Ukraine chose a model for the organization and implementation of state power according to the standards of modern developed European states, which in turn caused a rapid development of entrepreneurship and the economy. The core of protecting the interests of business entities was the system of economic courts, which, in their economic component, have a high economic value. Today, economic justice, in spite of constant pressure, is the most effective branch of the judicial system for resolving commercial disputes. The economic process differs from other processes: the timeliness of the proceedings; the quality of the decision; the calmness of the trial, since even open meetings are held in a separate room without the presence of the participants in the next process, which increases the attention of the court and the 
parties to the substance of the dispute; the ability of judges not only to solve the "in-law" case, but also to apply all democratic procedures for the peaceful resolution of the conflict. At the same time, it is necessary to draw the attention of the legislator to the fact that in spite of the impeccability of a certain mechanism of economic court proceedings, the courts act in full compliance with the current legislation, and modern legislation should not lag behind the realities of the world economy and justice, which are in constant dynamics and be one step ahead. Exploring the experience of the Anglo-Saxon legal system, the issue of adversarialism in the trial is widely discussed, which is perceived as an element of effective resolution of the dispute. According to our convictions, the court can not act as a passive role as an instrument for the abuse of experienced lawyers on the one hand and less experienced on the other, and should take an active part in obtaining comprehensive, complete and objective evidence for the correct application of the law. Of course, in the economic process, more backlash compared with other processes for competition. At the same time, the legislator needs to develop a framework for admissibility, as an ideologue of a modern, developed democratic legal state stands - effective and just justice.

The key words: judicial system, judicial power, economic courts, justice, legal proceeding.

\section{REFERENCES}

Dal', V.I. (2006). Tolkovyj slovar' zhivogo velikorusskogo jazyka [Explanatory Dictionary of the Living Great Russian Language]. Vol. 3. Moscow: Ripol klassik. [in Russian].

Gubenok, I.V. (2006). K voprosu o ponjatii jeffektivnogo pravosudija [On the issue of the concept of effective justice]. Juridicheskaja nauka i pravoohranitel'naja praktika [Legal science and law enforcement practice], no. 1, 109-112. [in Russian].

Kitaeva, A.G., Kitaeva, N.G. (2016). Genezis principov pravosudija [Genesis of the Principles of Justice]. Innovacionnaja nauka [Innovative Science], no. 4-4, 146-149. [in Russian].

Lunin, S.V. (2011). Pryntsyp zmahalnosti storin yak konstytutsiina harantiia spravedlyvoho sudochynstva [The principle of adversarial parties as a constitutional guarantee of fair legal proceedings]. Kyiv. [in Ukrainian].

Shishkin, C.A. (1997). Sostjazatel'nost' v grazhdanskom i arbitrazhnom sudoproizvodstve [Competitiveness in civil and arbitration proceedings]. Moscow: Juridicheskoe bjuro Gorodec. [in Russian].

Tihomirov, M.Ju. (Ed.). (1997). Juridicheskaja jenciklopedija [Law Encyclopedia]. Moscow: Jurinformcentr. [in Russian]. 


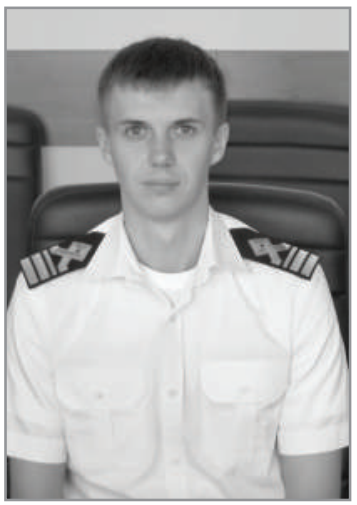

Степанов С. B.,

к. ю. н., доцент кафедри

цивільного і трудового права

Національного університету

«Одеська морська академія»

(м. Одеса, Україна)

ORCID: http://orcid.org/0000-0001-6371-7672

\section{ГОСПОДАРСЬКІ СУДИ УКРАЇНИ В СИСТЕМІ ОРГАНІВ СУДОВОЇ ВЛАДИ}

У статті визначено місце господарських судів в системі організації судової влади та виділена їх роль як інструменту вирішення економічних спорів в умовах розвитку сучасних ринкових відносин в Україні. Автором виявлено прогалини та недоліки законодавчого та правозастосовного характеру, які негативно впливають на привабливість України для руху людей та капіталу, висловлені пропозиції, спрямовані на їх усунення. Результатом дослідження є теоретичні висновки і практичні пропозиції щодо вдосконалення чинного законодавства в зазначеній галузі.

Ключові слова: судова система, судова влада, господарські суди, правосуддя, судочинство.

Sergiy Stepanov. Economic Courts of Ukraine are in the System of Judicial Authorities. - Article.

The article defines the place of economic courts in the system of organization of the judiciary, and their role as an instrument for resolving economic disputes in the conditions of the development of modern market relations in Ukraine is singled out. The author identified gaps and deficiencies in the legislative and law enforcement nature that adversely affect the attractiveness of Ukraine for the movement of people and capital, and made proposals aimed at their elimination. The result of the research is theoretical conclusions and practical suggestions for improving the current legislation in this area.

Keywords: judicial system, judicial power, economic courts, justice, legal proceeding.

(C) Степанов C. B., 2018 
Степанов С. В. Хозяйственные суды Украины в системе органов судебной власти. - Статья.

В статье определено место хозяйственных судов в системе организации судебной власти и выделена их роль как инструмента разрешения экономических споров в условиях развития современных рыночных отношений в Украине. Автором выявлены пробелы и недостатки законодательного и правоприменительного характера, которые негативно влияют на привлекательность Украины для движения людей и капитала, высказаны предложения, направленные на их устранение. Результатом исследования является теоретические выводы и практические предложения по совершенствованию действующего законодательства в указанной области.

Ключевые слова: судебная система, судебная власть, хозяйственные суды, правосудие, судопроизводство.

Правосуддя є особливим, специфічним видом юридичної діяльності, яку держава покладає на діючу судову владу країни.

В. I. Даль у тлумачному словнику термінів надає визначення правосуддя як «особливого виду державної (публічної) діяльності, яка полягає в тому, що незалежний, неупереджений і справедливий суд (суди) на основі закону розглядає і вирішує правові спори і справи, віднесені до його відання, у встановлених законом правових формах» [1, с. 380].

Сукупність владної компетенції судів, які виносять загальнообов'язкові для фізичних, юридичних осіб, держави і муніципальних утворень рішення, з обов'язковими для всіх без винятку учасників судового процесу правилами процедури, все це визначає специфіку правосуддя, що представляє особливий рід діяльності, характерний лише для судів.

Правосуддю, що здійснюється за допомогою окремих видів судочинства, властиві специфічні загальні сутнісні характеристики і принципи. До таких належать закріплені в чинній Конституції України та законах положення щодо незалежності судів і суддів, підпорядкування їх лише чинному законодавству, про відкритий розгляд справ в судових засіданнях (за винятком випадків, прямо передбачених законом), здійснення правосуддя на засадах змагальності і рівноправності зацікавлених сторін.

Самі правові теорії, принципи правосуддя, окремі їх аспекти були сформульовані ще за часів Римської імперії. 3 часом принципи почали формулюватися законодавцем i знаходили закріплення в нормах права, що і дозволяє казати про наявність саме правових принципів. 
А. Г. Китаєва відзначає, що «принципи правосуддя мають подвійну природу. 3 одного боку, вони є об'єктивними, оскільки виводяться 3 об'єктивно існуючої реальності. 3 іншого боку, вони і суб'єктивні, оскільки зароджуються в процесі повсякденної людської діяльності і пропускаються через мислення конкретних людей» [2, с. 147].

Значення принципу правосуддя, як його здійснення лише судом, полягає в закріпленні на державному рівні такої істини, що лише суд є остаточною, єдиною інстанцією, яка визначає правомочну сторону в спорі.

У Конституції України прямо вказано, що «Правосуддя в Україні здійснюють виключно суди. Делегування функцій судів, а також привласнення цих функцій іншими органами чи посадовими особами не допускаються». Тобто, будь-яка дія, будь-якої гілки влади може бути оскаржена у судовому порядку, що виключає свавілля органів державної влади, які можуть зловживати своїм статусом органа владних повноважень.

Держава, закріплюючи принцип здійснення правосуддя тільки судом, гарантує кожній людині законність, обгрунтованість, вмотивованість, справедливість рішень по спорам і справам, що виникають.

Звісно ж вірною $є$ точка зору тих вчених, які характеризують правосуддя в додатку до всіх видів судочинства. М. Ю. Тихомиров приходить до висновку, що правосуддя «це здійснювана в процесуальному порядку правозастосовна діяльність суду з розгляду і вирішення цивільних і кримінальних справ, а також економічних спорів 3 метою охорони прав та інтересів громадян, суспільства і держави» [3, с. 347].

I. В. Губенок, звертає увагу на цілі, заради яких здійснюється правосуддя, а саме у захисті та охороні прав і інтересів громадян [4, с. 109].

Судова влада на сучасному етапі існування демократичного суспільства займає найважливіше місце серед органів державної влади.

Сучасна модель організації судових органів полягає у розподіленні повноважень між судовими інстанціями за профільною ознакою відповідно до сфери суспільних відносин, де кожен судовий інститут розглядає певну групу суспільних відносин: цивільних, адміністративних, господарських, конституційних та кримінальних, які разом утворюють єдину судову систему.

Поділ повноважень має дуже велике значення не лише для поліпшення якості правосуддя, розподілу судових установ на місцях за ступенем завантаженості, але і для спрощення процедури звернення до компетентної судової інстанції фізичними та юридичними особами. 
Під час проголошення незалежності Україна обрала модель організації та здійснення державної влади за стандартами сучасних розвинених європейських держав, що, у свою чергу, викликало бурхливий розвиток підприємництва та економіки. Це, в свою чергу, зумовило розвиток законодавства, що регламентує відносини в сфері підприємницької та іншої економічної діяльності. Конфлікти, що виникають при здійсненні економічної діяльності, більша їх частина, вирішується учасниками обороту самостійно, з урахуванням взаємних інтересів на компромісній основі.

При неможливості мирного вирішення конфлікту сторона, яка вважає, що іiі права порушені, звертається до суду з метою захисту права і врегулювання спору.

Особлива роль судової системи визнається і на державному рівні.

Відповідно до ст. 55 Конституції України, кожному гарантується право на судовий захист своїх прав і свобод, а правосуддя в Україні здійснюється виключно судами (ст. 124).

Необхідність захисту прав та інтересів суб' єктів підприємницької діяльності стало причиною вдосконалення судової системи держави, як в аспекті судоустрою, так і з точки зору судочинства.

Зміна соціально-політичного і економічного курсу, що відбувся в Україні, впровадження ринкових відносин в економіку, відмова від адміністративно-планових методів управління економічними процесами, конституційне закріплення права кожного на вільне використання своїх здібностей і майна для підприємницької та іншої не забороненої законом економічної діяльності, стало причиною вдосконалення судової системи держави, як у аспекті судоустрою, так і 3 точки зору судочинства.

Якщо брати за зразок європейський та американський досвід, або навіть власний історичний досвід, то захистом прав та інтересів суб'єктів економічної діяльності раніше завжди займались спеціальні комерційні (торгові) суди, це і стало фундаментом для формування спеціалізованих господарських судів України.

Основною метою діяльності господарських судів є здійснення правосуддя в сфері підприємницької та іншої економічної діяльності, тобто вирішення спорів, які за своєю економічною складовою мають велику економічну цінність. Останні 26 років судова система України пройшла великий шлях реформування та впровадження нових механізмів, які позитивно та негативно впливали на судо- 
чинство. Господарське судочинство враховуючи його особливу роль для економіки країни, залучення іноземних інвесторів та капіталу, від початку свого існування також були під постійною увагою влади. Кожна реформа судочинства не обходилась без обговорення доцільності існування господарського судочинства як самостійної гілки у системі судів, тому наука господарського права 26 років пліч о пліч із суддями відстоюють необхідність збереження господарських судів.

За роки незалежності господарські суди підвищували свій професійний рівень. Великий колектив досвідчених професійних суддів постійно поповнюють молоді судді, які завдяки ефективній команді, вдалій структурі, підготовці та організації господарського судочинства у найкоротші строки приступають до виконання своїх професійних обов'язків на високому теоретичному та практичному рівні. У процесі практичної діяльності на базі судів постійно проводяться наукові семінари, конференції та круглі столи, які розвивають та підвищують професійний рівень суддів.

Сьогодні господарське судочинство, незважаючи на постійний тиск, є найбільш ефективною гілкою судової системи 3 вирішення комерційних спорів. Господарський процес відрізняється від інших процесів: своєчасністю строків розгляду справи; якістю винесеного рішення; спокійністю судового процесу, оскільки навіть відкриті засідання проводяться у окремому залі, без присутності учасників наступного процесу, що підвищує увагу суду та сторін до суті спору; вмінням суддів не лише вирішити справу за законом, але й застосувати всі демократичні процедури з мирного вирішення конфлікту.

При цьому необхідно звернути увагу законодавця, що, незважаючи на бездоганність механізму розгляду справ, господарські суди діють у повній відповідності до діючого законодавства, тому, зважаючи на особливу економічну роль господарського судочинства, сучасне законодавство не повинно відставати від реалій світової економіки та судочинства, які знаходяться у постійній динаміці та бути на крок попереду.

Наприклад, Конституція України не визначає правове положення юридичних осіб, щодо захисту своїх порушених прав та інтересів.

Частина 1 статті 55 «Права і свободи людини і громадянина захищаються судом» зазначає, що «Кожному гарантується право на оскарження в суді рішень, дій чи бездіяльності органів державної влади, органів місцевого самоврядування, посадових і службових осіб». 
На наш погляд, вказану статтю необхідно доповнити положенням наступного змісту: «Юридичні особи мають рівні з громадянами права на звернення до суду за захистом своїх інтересів».

Також необхідно звернути увагу на законодавче врегулювання питання ліквідації та реорганізації судів.

Відомо, що відповідно до ст. 6 Конституції України, державна влада в Україні здійснюється на засадах ії поділу на законодавчу, виконавчу та судову. Органи законодавчої, виконавчої та судової влади здійснюють свої повноваження у встановлених Конституцією межах і відповідно до законів України. Цей поділ є розумним, справедливим та найбільш прийнятним у світі. Відповідно до принципу поділу влади, кожна гілка влада покликана виконувати власні функції та не втручатись у діяльність інших гілок.

Натомість сьогодні у процесі утворення та ліквідації (реорганізаціi) судів задіяні всі гілки державної влади, оскільки вищевказаними питаннями та питаннями формування складу суддів займаються Верховна рада України, яка приймає закон, Президент - подає закон про утворення або ліквідацію суду, Вища рада правосуддя - проводить консультування Президента (до речі, обмеженість ії повноважень також викликає великі сумніви, щодо належності у неї реальної влади. Можна навіть сказати, що вона наділена «квазі-владою»), Державна судова адміністрація України - погоджує з Вищою радою правосуддя кількісний склад суддів суду. Отже, у процес формування та діяльності судової влади включені всі існуючі гілки влади, і звісно про незалежність та неупередженість судової влади як незалежної гілки влади дуже складно казати.

Також у наукових колах при дослідженні досвіду англо-саксонської правової системи широко обговорюється питання змагальності у судовому процесі. Так, у цих країнах змагальність сприймається як елемент ефективного вирішення спору. Суддя займається дослідженням лише матеріальної сторони справи, сторони, у свою чергу, змагаються в обгрунтуванні необхідності покладення в основу рішення саме їх доказів [5, с. 10-15]. Необхідно погодитись із позицією С. О. Шишкіна, який вказує на те, що на суд покладено обов'язок створити необхідні умови для всебічного й повного дослідження обставин справи, сприяти сторонам у здійсненні їх прав [6, с. 61, 122, 139].

За нашим переконанням змагальність національного судочинства проявляється зацікавленістю сторін у результатах спору. Наприклад, 
якщо позивач без поважних причин не з'явився у судове засідання, що перешкоджає вирішенню спору, суддя може залишити заяву без розгляду, тим самим мотивуючи позивача до змагальних дій. Суд не може виконувати пасивну роль як інструмент для зловживання у руках досвідчених адвокатів з однієї сторони та менш досвідчених з іншої, а повинен приймати активну участь для отримання всебічних, повних та об'єктивних фактичних даних для правильного застосування законодавства.

Звісно у господарському процесі більший люфт порівняно 3 іншими процесами для змагальності. При цьому законодавцю необхідно розробити рамки допустимості, оскільки ідеологемою сучасної розвиненої демократичної правової держави виступає ефективне та справедливе правосуддя.

Таким чином, за результатом проведеного дослідження представляється можливим визначити правосуддя як особливий вид державної діяльності, який полягає в тому, що на підставі чинного законодавства незалежний, неупереджений і справедливий суд розглядає і вирішує правові спори і справи за допомогою конституційного, цивільного, господарського, адміністративного та кримінального судочинства.

Щодо ролі господарських судів в системі організації судової влади України можна зробити висновок, що поділ судової системи України за профільною ознакою не лише знижує навантаження на суди, але i створює певну упорядкованість справ за типологією, що безумовно $€$ обгрунтованим.

Дискусія щодо доцільності існування будь-якої судової вертикалі (або господарських, або адміністративних судів) та іiі ліквідації на державному рівні, призведе до колапсу налагодженої системи правосуддя України.

Таким чином, господарські суди - самостійна частина судової системи України, структурний елемент механізму сучасної Української держави, який займає одне з провідних місць у системі забезпечення законних прав та інтересів учасників економічного обороту, який за роки незалежності зарекомендував себе у якості найбільш результативної гілки судової системи.

Особливістю господарського процесу виступає специфіка матеріальних правовідносин, що дозволяє ефективно захистити порушені чи оспорювані права і законні інтереси осіб (переважно юридичних), які здійснюють підприємницьку та іншу економічну діяльність. 
Господарський процес відрізняється від інших процесів: своєчасністю строків розгляду справи; якістю винесеного рішення; спокійністю судового процесу, оскільки навіть відкриті засідання проводяться у окремому залі, без присутності учасників наступного процесу, що підвищує увагу суду та сторін до суті спору; вмінням суддів не лише вирішити справу за законом, але й застосувати всі демократичні процедури з мирного вирішення конфлікту.

При цьому необхідно звернути увагу законодавця, що, незважаючи на бездоганність певного механізму, господарські суди діють у повній відповідності до діючого законодавства, тому, зважаючи на особливу економічну роль господарського судочинства, сучасне законодавство не повинно відставати від реалій світової економіки та судочинства, які знаходяться у постійній динаміці та бути на крок попереду.

\section{ЛІТЕРАТУРА}

1. Даль В. И. Толковый словарь живого великорусского языка. В 4 т. Т. 3. М.: Рипол классик, 2006. 549 с.

2. Китаева А. Г., Китаева Н.Г. Генезис принципов правосудия // Инновационная наука. 2016. № 4-4. С. 146-149.

3. Тихомиров М. Ю., Тихомирова Л. В. Юридическая энциклопедия / Под ред. М. Ю. Тихомирова. - М.: Юринформцентр, 1997. 525 с.

4. Губенок И. В. К вопросу о понятии эффективного правосудия // Юридическая наука и правоохранительная практика. 2006. № 1. С. 109-112.

5. Лунін С. В. Принцип змагальності сторін як конституційна гарантія справедливого судочинства: автореф. дис. канд. юрид. наук. - К., 2011. 19 с.

6. Шишкин С. А. Состязательность в гражданском и арбитражном судопроизводстве. - М.: Юридическое бюро Городец, 1997. 192 с. 